Assiut Scientific Nursing Journal

http://asnj.journals.ekb.eg

http://www.arabimpactfactor.com

\title{
Effect of Nursing Guidelines in Clinical Outcomes For Haematemesis Patients in Intensive Care Unit at Alrajhy Liver Hospital
}

\author{
Asmaa S. Mohamed ${ }^{1}$, Mervat A. Abdelaziz ${ }^{2}$ \& Asmaa A. Mahgoub ${ }^{3}$. \\ ${ }^{1 .}$ Specialist nursing at Alrajhy Liver Hospital, Assuit University, Egypt. \\ 2. Assistant professor of critical care and emergency nursing, faculty of nursing, Assuit University, Egypt. \\ ${ }^{3 .}$ Assistant professor of critical care and emergency nursing, faculty of nursing, Assuit University, Egypt.
}

\begin{abstract}
Many patients with hematemesis had multiple complications as hypovolemic shock than death. Patient in ICU need special nursing guidelines to improve their outcomes. Aim of the study: to evaluate the effect of nursing guidelines in clinical outcomes for haematemesis patients at gastroenterology intensive care unit. Research design: quasi experimental research design was utilized in this study. which was carried out in gastroenterology ICU at alrajhy liver hospital at assiut university. The study sample consisted of study group (50 patients) who received the nursing guidelines and control group (50 patients) who received routine care. The following tools were utilized for data collection: Tool I haematemesis assessment sheet Tool II evaluation through different score, Tool III patient outcome and complication. Tools were applied in 3 phases; preparatory, implementation and evaluation phase. method record and document patient social and medical data, hemodynamic, respiratory, and cardiovascular status, assessment of blood transfusion, laboratory data, assess the patient status using different scale, and finally complications, Results: The majority of control group developed hepatorenal syndrome but (2.0\%) patients in the study group had developed hepatorenal syndrome with higher in percentage in complication in control group than study group with significance difference $(\mathrm{P}<0.05)$. Conclusion: nursing guidelines leads to significant improvement in Patients outcomes for haematemesis patients. Recommendations suggest to emphasize the importance of accurate assessment of the patient with haematemesis
\end{abstract}

\section{Keywords: Effect, Nursing Guidelines, Patient's Outcomes \& Hematemesis.}

\section{Introduction}

Haematemesis is a common medical emergency characterised by acute upper gastrointestinal bleeding. massive haemorrhage from the upper GI tract may be associated with brighter rectal bleeding. haemodynamic instability may also feature, with patients presenting with dizziness, syncope or in hypovolaemic shock. (Reintam, et al., 2014)

Complications among patients with haematemesis such as liver failure, ascites, myocardial infarction, sedation related complications, hepatorenal failure, anemia, cerebrovascular stroke, pulmonary embolism, deep venous thrombosis, septicemia, heart failure and acute pulmonary edema due to over infusion. (Gado, et al., 2012).

The critical care nurse should be focused, in order to identify sources and complications of bleeding, abnormal vital signs can be used to identify patient in shock from haematemesis, skin, conjunctiva, and oral mucosa should be assessed for cyanosis, pallor which may indicate underlying liver disease, and head, eye, ear, nose, and throat examination should assess for sources of bleeding, the abdomen should be examined for surgical scars, hepatosplenomegaly, or any other signs that indicate the possibility of liver disease and cirrhosis, abdominal tenderness can indicate underlying peptic ulcer disease perforation or other intra-abdominal pathology; however, there is signifcant variability. (Smith, 2014)

The initial stabilization must include the evaluation of the airways, respiration and circulation, venous access, and the collection of laboratory exams, in addition to, when indicated, the administration of fluids, blood transfusion, cardiorespiratory support, and treatment of diseases, such as sepsis or acute myocardial infactions. In patients that present respiratory insufficiency or hemodynamic instability, the endoscopy should be delayed until the patient is adequately resuscitated and stabilized. (Kwan, Norton 2017)

Initial laboratory tests include measurement of hemoglobin, hematocrit, blood urea nitrogen, and creatinine; platelet count; prothrombin time; international normalized ratio; liver function tests; and type and crossmatch. Patients with active bleeding and coagulopathy should be considered for transfusion with fresh frozen plasma, and those with active bleeding and thrombocytopenia should be considered for transfusion with platelets. Blood transfusions generally should be administered to those with a hemoglobin level of $7 \mathrm{~g}$ per $\mathrm{dL}(70 \mathrm{~g}$ per $\mathrm{L})$ or less; hemoglobin level should be maintained at $9 \mathrm{~g}$ per dL (90 g per L). (Jairath, et al., 2010) 
General support measures, patients receive supplementary oxygen by nasal catheter to compensate for the loss of the carrier capacity of oxygen, due to the loss of red blood cells. In the presence of massive bleeding, persistent hematemesis, hypoxia, tachypnea, or alteration of one's mental state, an immediate and definitive airway must be evaluated to protect the aspiration. (Rudolph et al., 2013).

Non-invasive monitoring with oximetry and blood pressure, and continuous ECG are recommended. In patients with hemodynamic instability, it may be necessary to apply an invasive monitoring with central venous pressure. foley catheter is indicated in patients in a state of shock, or in those that present massive bleeding, in order to control urinary output. (McIntyre et al., 2015)

Nasogastric catheter, the passage for gastric irrigation with saline solution is beneficial to detect the presence, aspect, and volume of blood, to clean the field for endoscopic visualization, and to prevent the aspiration of gastric contents (Cappell, 2015) Nasogastric lavage is often used to aspirate a patient's stomach contents in an effort to improve the view of the anatomy during endoscopy. (Aljebreen, Fallone, et al 2014 )

\section{Significant of study}

Statistical reports of gastroenterology intensive care unit at alrajhy liver hospital in assuit university documented that 500 cases diagnosed with haematemesis from 4592 cases the total case enter hospital between 2015 to2016.

\section{Aim of the study}

To evaluate the effect of nursing guidelines on the outcomes of patients with haematemesis at gastroenterology intensive care unit.

\section{Hypotheses}

To fulfill the aim of this study the following hypotheses will be formulated:-

Patients who receive nursing guidelines exhibit lesser hospital stay.

Patients who receive nursing guidelines better hemodynamic stability.

Patients who receive nursing guidelines lesser liver failure occurrence.

Patients who receive nursing guidelines lesser hepatorenal failure occurrence.

\section{Material and Methods}

Research Design: Quasi-experimental research design was used to conduct this study.

\section{Variables:}

Independent variable is the nursing guidelines in patients with haematemesis.

Dependent variable is length of hospital stay, liver failure, hepatorenal failure and acute pulmonary edema.

\section{Setting of the study}

The study was carried out at gastroenterology intensive care unit at alrajhy liver hospital at assiut university. The ICU consist of 2 rooms each room involved 6 beds. Sample

A convenience sample of (100 patients) who diagnosed with haematemesis, divided into control Group (50 patients) and study Group (50 patients), their Aged from 18 to 60 years, from both sex, and Patients with pancreatitis, blood disorders, cancer patients, chronic upper gastrointestinal bleeding, bleeding lower than the duodenum and patients treated for helicobacter pylori were excluded.

\section{Study Tools}

\section{Three tools were used in this study}

Three tools was utilized to collect data in this study; they are developed by the researcher after passing through an extensive and relevant review of literature (Said, Williams, Holden, et al., 2014), (Ortiz, Córdoba, et al., 2017), (Green 2011). The validity \& reliability of these tools was reviewed by a panel of 3 critical care nursing and 2 medical experts, and then pilot study was done.

TOOL (I): Haematemesis assessment sheet: This tool was developed by the researcher based on reviewing of the relevant literature and used to assess the studied patients regard the socio-demographic data and medical related data as base line data, it includes three main parts as flowing.

\section{Part 1: Demographic and medical data}

Demographic data includes patient's code, age, sex, level of education, address, occupation and marital status.

Medical data includes diagnosis, date of admission, date of discharge, past history of diseases and allergy for any medications in addition to laboratory investigation.

Part 2: patient assessment sheet include

Hemodynamic and cardiovascular assessment: temperature, respiration, pulse rate and mean arterial pressure and CVP.

Operational definition:-

Hemodynamic means represented by clinical features of circularly shock and vital signs abnormalities.

Fluids Balance includes assessment of fluid balance by calculate total intake and output over 24 hour and then the total balance.

Total blood transfusion assessment over 24 hour. Medications administration it includes assess dose, duration, routes of administration and frequency for each type.

Record of endoscopic finding following endoscopy. General patient statues assessment to identify sources and complications of bleeding. 
Part 3: Gastrointestinal bleeding scale assessment the scale comprises four grade: grade1 ( positive stool occult blood test), grade2 ( melanotic stool, hematochezia - visible red blood mixed in stool, not requiring a transfusion, hematemesis - grossly visible blood in emesis or in nasogastric drainage tube), grade3 ( any bleeding requiring $\mathrm{RBC}$ transfusion over routine transfusion needs), grade4 ( any bleeding associated with severe hemodynamic instability, fatal bleeding from any source ). (WHO bleeding scale )

TOOL (II): Evaluation through different score / scale

Part 1:- Model for End-stage Liver Disease (MELD) Score

The Model for End-Stage Liver Disease (MELD) is a reliable measure of mortality risk in patients with end-stage liver disease. It is used as a disease severity index to help prioritize allocation of organs for transplant. These models are for use by medical professionals. This score include three biochemical markers serum bilirubin, serum creatinine, and international normalized ratio (INR). The MELD score ranged from 4 to 60 points. (Said, Williams, Holden, et al., 2014 )

Part 2: Hepatic Encephalopathy Grades/Stages: Hepatic encephalopathy Grades adopted from (Ortiz, Córdoba, et al., 2017).Hepatic encephalopathy is a syndrome observed in patients with cirrhosis, is defined as a spectrum of neuropsychiatric abnormalities in patients with liver dysfunction, after exclusion of brain disease. Hepatic encephalopathy is characterized by personality changes, intellectual impairment, and a depressed level of consciousness. Hepatic Encephalopathy Grades range from (Grade 0: Minimal HE, Grade 1: Mild HE, Grade 2: Moderate HE, Grade 3: Severe HE, Grade 4: Coma). Part 3:- Assessment of level of consciousness using (GCS):-

the Glasgow Coma Scale that developed by Green 2011 is a neurological scale aims to give a reliable, objective way of recording the conscious state of a person for initial as well as subsequent assessment. The scale comprises three tests: Best eye response (E) there are 4 grades starting with the most severe, best verbal response $(\mathrm{V})$ there are 5 grades starting with the most severe, and best motor response (M) there are 6 grades starting with the most severe responses. In the GCS, each of the component scores as well as the sum of the components is considered. The total score is out of 15-points, with lower scores indicating more severe impairment. The lowest possible GCS total score is 3 , indicating deep coma or death, and the highest possible score is 15 , indicating a fully awake individual (http://strokengine, 2006) The Scoring system for GCS is.
Severe $=$ GCS $\leq 8$

Moderate $=$ GCS $9-12$

Mild $=$ GCS $\geq 13$.

TOOL (III): Clinical out comes and complication assessment:

Many complications may occur such as mortality and morbidity, renal complication, hypovolemic shock, disturbed level of conscious, liver failure, hepatorenal failure and pulmonary edema, and ICU stay.

\section{Methods}

The study was conducted throughout three main phases which are preparatory phase, implementation phase and evaluation phase.

\section{Preparatory phase}

An Official permission was obtained from Dean of the faculty of nursing Assuit University to conduct the study was delivered to the hospital authorities at Al rajhy Liver Hospital at Assuit university hospital and approval to collect the necessary data after explain the purpose and nature of the study.

Informed consent was obtained from the head of the gastroenterology Intensive care unit at al rajhy liver hospital at assiut university was obtained.

The tools used in this study were developed by the researcher based upon review of the related literatures.

\section{Ethical considerations}

Research proposal was approved from Ethical Committee in the faculty of nursing.

There was no risk for study subject during application of the study .

The study followed common ethical principles in clinical research.oral consent was obtained from patients or guidance that participated in the study, after explaining the nature and purpose of the study.

Patient was assured that the data of this research will not be reused without second permission.

Confidentiality and anonymity was assured.

Patients had the right to refuse to participate or withdraw from the study without any rational at any time.

\section{Apilot study}

Carried out before starting of data collection to test the feasibility and clarity of the study tools on $10 \%$ of the sample, the analysis of pilot study define the modification required in the tool used, and the necessary modification was done prior to data collection. The studied subjects were excluded from the actual study.

\section{Statistical analysis}

Data collected and analysis by computer program SPSS "ver, 23" Chicago, USA. Data expressed as mean, standard deviation, number, and percentage. Using $\mathrm{T}$-test to determine significant for numeric 
variable. Using Chi-squar to determine significant for non-parametric variable.

n.s: $\mathrm{P}>0.05$ non-significant

*: $\mathrm{P}<0.05$ significant

**: $\mathrm{P}<0.005$ moderate significant

***: $\mathrm{P}<0.001$ highly significant

Data collection: The data were collected from the first day of admission until discharge from Gastroenterology Intensive Care Unit.

\section{Implementation phase}

The studied sample fulfilling the research criteria was assigned into two groups (study group and control group).

\section{For both groups}

Record of demographic data which include (age, address, sex, occupation, marital status) once on admission by using tool 1 part 1 .

Record of laboratory data on admission and then according to the hospital routine which include (PT, PC, INR, HB, HTC, ABG, Cross match for blood transfusion, complete Liver function tests, urea, Creatinine, $\mathrm{Ca}, \mathrm{Mg}, \mathrm{k}, \mathrm{Na}$ ) by using tool 1 part 1.

Record of hemodynamic, respiratory, and cardiovascular status which include (heart rate, respiratory rate, MABP, oxygen saturation) every day from admission day until discharge by using bedside monitor using tool 1 part 2.

Assessment of total fluid balance, total blood transfusion from admission day until discharge every 24 hour by using fluid chart using tool 1 part 2.

Assessment of total blood transfusion from admission day until discharge every 24 hour using tool 1 part 2. Apply gastric lavage.
Administration of antibleeding drugs.

Demonstrate enema to reduce the incidence of hepatic encephalopacy.

Prepare patient for endoscopy.

For study group

Assess the patient for gastrointestinal bleeding by gastrointestinal bleeding scale every day from admission until discharge by using tool 1 part 3 .

Evaluate the patient for cirrhosis and mortality using MELD score every day from admission until discharge by using tool 2 part 1 .

Assess the patient for hepatic encephalopathy grades every day from admission until discharge by using tool 2 part 2.

Assess the patient level of consciousness using GCS and Hepatic encephalopathy scale every day from admission until discharge by using tool 2 part 3 .

Record of complications of the disease every day from admission until discharge by using tool 3.

Medical history, physical exam, and initial laboratory exams.

Non-invasive monitoring to patient.

Correcting fluid losses and restoring hemodynamic stability.

Blood transfusions.

Patients receive supplementary oxygen.

Antibiotics to reduce infection incidence.

\section{Evaluation phase}

Both control and study group were evaluated for four day every day using the assessment sheet to determine the effect of nursing guideline applied to the study group.

\section{Results}

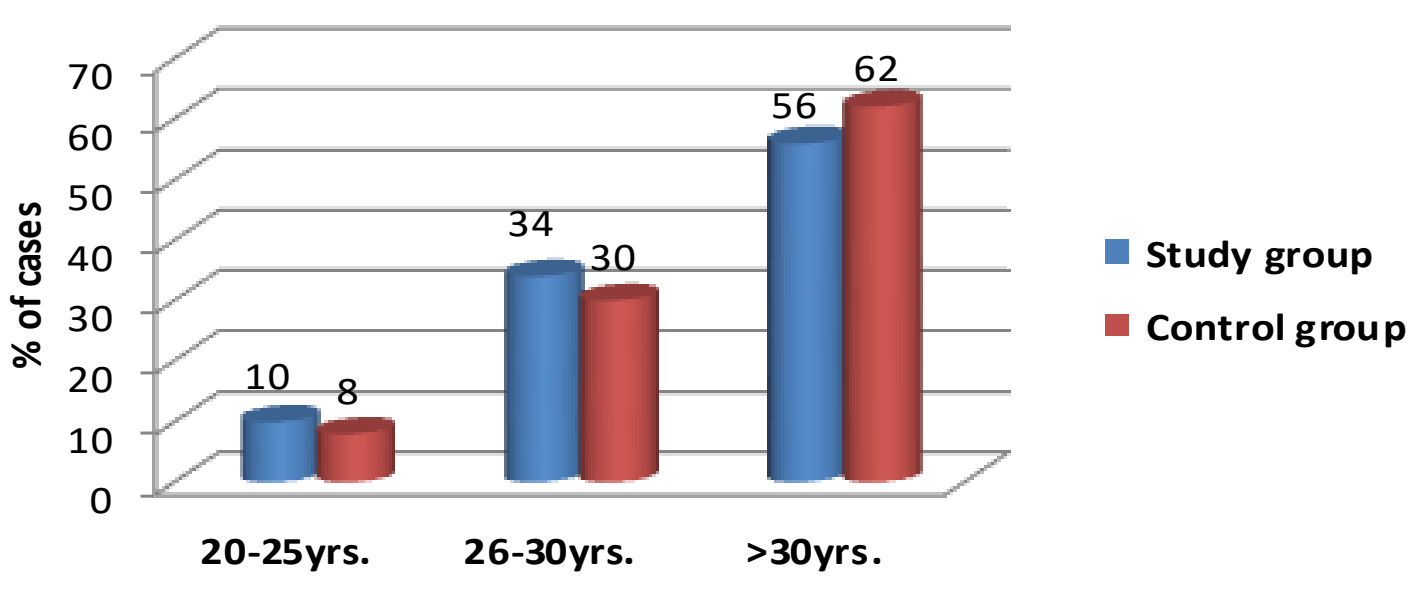

Fig (1): Comparison between the study and control groups in relation to Age. 


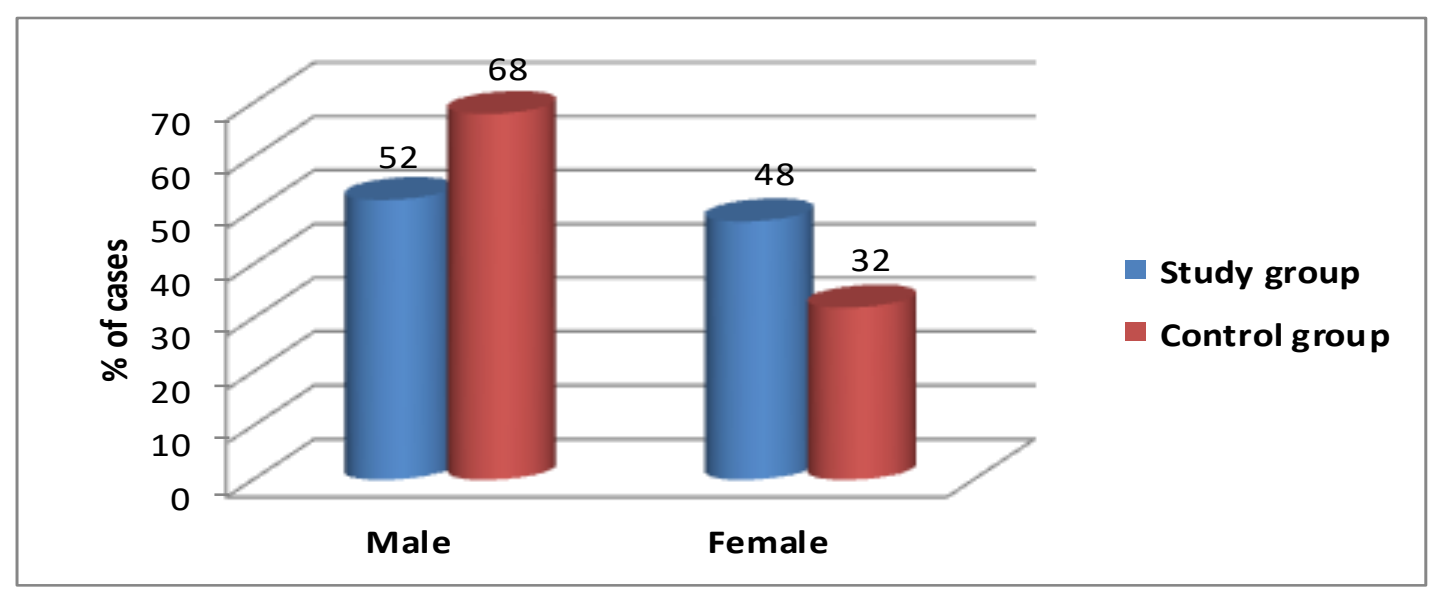

Fig (2): Comparison between the study and control groups in relation to Gender distribution.

Table (1): Comparison between both study and control groups regard medical data and past medical history and cause of haematemesis.

\begin{tabular}{|c|c|c|c|c|c|}
\hline \multirow{2}{*}{ Medical data } & \multicolumn{2}{|c|}{$\begin{array}{c}\text { Study group } \\
\text { "n=50" }\end{array}$} & \multicolumn{2}{|c|}{$\begin{array}{c}\text { Control group } \\
" \mathrm{n}=50 "\end{array}$} & \multirow{2}{*}{$\begin{array}{c}\text { Significance } \\
\text { test }\end{array}$} \\
\hline & $\mathbf{N}$ & $\%$ & $\mathbf{N}$ & $\%$ & \\
\hline \multicolumn{5}{|c|}{ past history of disease: } & $P=0.483^{n . s}$ \\
\hline Diabetes Mellitus & 6 & $12.0 \%$ & 7 & $14.0 \%$ & $\mathbf{P}<0.37^{2 n . s}$ \\
\hline Hypertension & 7 & $14.0 \%$ & 9 & $18.0 \%$ & $P=0.473^{n . s}$ \\
\hline Allergy for any medication & 0 & 0 & 0 & 0 & $\mathbf{0}$ \\
\hline Past family history & 18 & $36.0 \%$ & 20 & $40.0 \%$ & $P=0.483^{n . s}$ \\
\hline \multicolumn{5}{|c|}{ Causes of haematemesis: } & \\
\hline Without liver cirrhosis (peptic ulcer) & 7 & $14.0 \%$ & 7 & $14.0 \%$ & \multirow{2}{*}{$P=0.394^{\text {n.s }}$} \\
\hline Liver cirrhosis & 43 & $86.0 \%$ & 43 & $86.0 \%$ & \\
\hline
\end{tabular}

*: $P<0.05$ significant

Data described as(n\& \%) chi-squar test and (mean $\pm S D$ independent sample t-test

Table (2): Comparison between both study and control groups regard Physical examination.

\begin{tabular}{|c|c|c|c|c|c|}
\hline \multirow{2}{*}{ Physical examination } & \multicolumn{2}{|c|}{ Study group “n=50" } & \multicolumn{2}{|c|}{ Control group "n=50" } & \multirow{2}{*}{ Significance test } \\
\hline & $\mathbf{N}$ & $\%$ & $\mathbf{N}$ & $\%$ & \\
\hline \multicolumn{5}{|c|}{ Assess skin \& oral mucosa } & \multirow{4}{*}{$\mathrm{P}=0.500^{\mathrm{n} . \mathrm{s}}$} \\
\hline Normal & 0 & 0 & 1 & $2.0 \%$ & \\
\hline Cyanosis & 0 & 0 & 0 & 0 & \\
\hline Pallor & 50 & $100 \%$ & 49 & $98.0 \%$ & \\
\hline \multicolumn{5}{|c|}{ Abdomen } & \multirow{6}{*}{$P=0.0758^{\text {n.s }}$} \\
\hline Normal & 0 & 0 & 0 & 0 & \\
\hline Surgical scars & 0 & 0 & 2 & $4.0 \%$ & \\
\hline Abdominal tenderness & 50 & $100 \%$ & 45 & $90.0 \%$ & \\
\hline Hernia & 0 & 0 & 3 & 6.0 & \\
\hline Ascites & 37 & $74 \%$ & 45 & $90.0 \%$ & \\
\hline
\end{tabular}

$*: P<0.05$ significant

Data described as(n\&\%) chi-squar test and (mean $\pm S D$ independent sample t-test 
Table (3): Comparison between both study and control groups in relation to Hemodynamic status.

\begin{tabular}{|c|c|c|c|}
\hline \multirow{2}{*}{ Hemodynamic status } & Study group "n=50" & Control group " $n=50 "$ & \multirow[b]{2}{*}{ Significance tes } \\
\hline & Mean \pm SD & Mean \pm SD & \\
\hline \multicolumn{4}{|c|}{ Temperature } \\
\hline 1st day & $36.95 \pm 0.19$ & $37.08 \pm 0.13$ & $\mathrm{P}=0.375^{\mathrm{n} . \mathrm{s}}$ \\
\hline 2nd day & $37.67 \pm 0.08$ & $38.01 \pm 0.93 \#$ & $\mathrm{P}=0.234^{\mathrm{n} . \mathrm{s}}$ \\
\hline 3rd day & $37.72 \pm 0.76$ & $39.23 \pm 0.52 \#$ & $\mathbf{P}<0.02^{*}$ \\
\hline Discharge day from ICU & $37.25 \pm 0.28$ & $39.34 \pm 0.32 \# \#$ & $\mathbf{P}<0.02^{*}$ \\
\hline \multicolumn{4}{|c|}{ Heart Rate } \\
\hline 1st day & $95.24 \pm 17.78$ & $93.87 \pm 15.39$ & $P=0.638^{n \cdot s}$ \\
\hline 2nd day & $105.12 \pm 12.06$ & $101.54 \pm 12.53$ & $\mathrm{P}=0.286^{\mathrm{n} . \mathrm{s}}$ \\
\hline Discharge day from ICU & $108.58 \pm 14.40$ & $105.70 \pm 10.32$ & $P=0.680^{\text {n.s }}$ \\
\hline 4th day & $112.35 \pm 10.45$ & $109.47 \pm 11.56$ & $\mathrm{P}=0.447^{\mathrm{n} . \mathrm{s}}$ \\
\hline \multicolumn{4}{|c|}{ Respiratory Rate } \\
\hline 1st day & $24.82 \pm 2.24$ & $23.67 \pm 3.01$ & $P=0.362^{n . s}$ \\
\hline 2nd day & $26.54 \pm 2.46$ & $26.34 \pm 2.31$ & $P=0.336^{\text {n.s }}$ \\
\hline 3rd day & $25.60 \pm 3.67$ & $26.78 \pm 3.02$ & $\mathrm{P}=0.372^{\text {n.s }}$ \\
\hline Discharge day from ICU & $26.32 \pm 2.78$ & $26.85 \pm 3.56$ & $\mathrm{P}=0.481^{\mathrm{n} . \mathrm{s}}$ \\
\hline \multicolumn{4}{|c|}{ Systolic blood pressure } \\
\hline 1rd day & $145.36 \pm 12.46$ & $146.37 \pm 12.47$ & $\mathrm{P}=0.473^{\mathrm{n} \cdot \mathrm{s}}$ \\
\hline 2rd day & $148.23 \pm 11.54$ & $145.34 \pm 13.25$ & $P=0.362^{n . s}$ \\
\hline 3rd day & $143.56 \pm 13.11$ & $144.68 \pm 12.35$ & $\mathrm{P}=\mathbf{0 . 5 8 3 ^ { \mathrm { n } . \mathrm { s } }}$ \\
\hline Discharge day from ICU & $144.02 \pm 10.35$ & $144.98 \pm 14.21$ & $P=0.447^{\text {n.s }}$ \\
\hline \multicolumn{4}{|c|}{ Diastolic blood pressure } \\
\hline 1rd day & $93.25 \pm 11.45$ & $95.37 \pm 13.08$ & $P=0.385^{\text {n.s }}$ \\
\hline 2rd day & $92.36 \pm 12.53$ & $94.67 \pm 13.56$ & $\mathrm{P}=0.482^{\mathrm{n} . \mathrm{s}}$ \\
\hline 3rd day & $93.37 \pm 10.78$ & $94.22 \pm 12.43$ & $P=0.337^{\text {n.s }}$ \\
\hline Discharge day from ICU & $93.68 \pm 2.13$ & $94.89 \pm 10.33$ & $\mathrm{P}=0.386^{\mathrm{n} . \mathrm{s}}$ \\
\hline \multicolumn{4}{|c|}{ Main arterial blood pressure } \\
\hline 1rd day & $71.04 \pm 6.46$ & $73.67 \pm 6.45$ & $\mathrm{P}=0.385^{\mathrm{n} . \mathrm{s}}$ \\
\hline 2rd day & $76.10 \pm 7.44 \#$ & $85.88 \pm 4.56 \#$ & $\mathbf{P}<0.001^{* * *}$ \\
\hline 3rd day & $81.40 \pm 5.62 \# \# \#$ & $86.03 \pm 8.56 \# \#$ & $\mathbf{P}<0.01^{*}$ \\
\hline Discharge day from ICU & $80.48 \pm 3.78 \# \# \#$ & $86.26 \pm 2.78 \# \#$ & $\mathbf{P}<0.0011^{* *}$ \\
\hline \multicolumn{4}{|c|}{ Oxygen saturation } \\
\hline 1rd day & $93.58 \pm 1.53$ & $92.96 \pm 2.79$ & $\mathrm{P}=0.274^{\mathrm{n} . \mathrm{s}}$ \\
\hline 2rd day & $92.14 \pm 13.91$ & $93.80 \pm 2.32$ & $\mathrm{P}=0.407^{\mathrm{n} . \mathrm{s}}$ \\
\hline 3rd day & $95.42 \pm 1.67$ & $94.70 \pm 2.32$ & $\mathrm{P}=0.084^{\mathrm{n} . \mathrm{s}}$ \\
\hline Discharge day from ICU & $96.50 \pm 1.73$ & $95.21 \pm 2.27$ & $\mathbf{P}=0.300^{\mathrm{n} . \mathrm{s}}$ \\
\hline
\end{tabular}

*: $P<0.05$ significant

Data described as $(n \& \%)$ chi-squar test and (mean $\pm S D$ independent sample t-test 
Table (4): Comparison between both study and control groups in relation to laboratory data.

\begin{tabular}{|c|c|c|c|}
\hline \multirow[t]{2}{*}{ Laboratory data } & $\begin{array}{c}\text { Study group } \\
\text { "n=50" }\end{array}$ & $\begin{array}{c}\text { Control group } \\
{ }^{6} \mathrm{n}=\mathbf{5 0 "}\end{array}$ & \multirow{2}{*}{ Significance test } \\
\hline & Mean \pm SD & Mean \pm SD & \\
\hline \multicolumn{4}{|c|}{ Blood test } \\
\hline Hemoglobin & $9.51 \pm 2.34$ & $7.47 \pm 2.34$ & $\mathrm{P}<0.03^{*}$ \\
\hline Hematocrit & $27.71 \pm 6.99$ & $22.79 \pm 6.60$ & $P<0.04^{*}$ \\
\hline \multicolumn{4}{|c|}{ Coagulation study } \\
\hline Prothrombin time & $13.80 \pm 3.07$ & $17.22 \pm 3.26$ & $\mathbf{P}<0.04^{*}$ \\
\hline Prothrombin concentration & $80.52 \pm 23.18$ & $96.56 \pm 2.98$ & $\mathrm{P}<0.04^{*}$ \\
\hline INR & $206.98 \pm 11.89$ & $267.45 \pm 13.67$ & $\mathbf{P}<0.01^{*}$ \\
\hline \multicolumn{4}{|c|}{ Electrolytes } \\
\hline Sodium & $1.13 \pm 0.15$ & $2.82 \pm 0.67$ & $P<0.03^{*}$ \\
\hline Potassium & $3.97 \pm 0.51$ & $4.12 \pm 0.22$ & $P=0.264^{n . s}$ \\
\hline Magnesium & $1.99 \pm 0.27$ & $1.98 \pm 0.38$ & $P=0.375^{\text {n.s }}$ \\
\hline Calcium & $8.82 \pm 0.71$ & $7.99 \pm 1.80$ & $\mathrm{P}=0.447^{\mathrm{n} . \mathrm{s}}$ \\
\hline \multicolumn{4}{|c|}{ Renal function test } \\
\hline Urea & $11.22 \pm 1.06$ & $12.34 \pm 1.18$ & $P=0.286^{n . s}$ \\
\hline Creatinine & $84.45 \pm 4.67$ & $97.45 \pm 2.67$ & $\mathbf{P}<0.02^{*}$ \\
\hline \multicolumn{4}{|c|}{ Liver function test } \\
\hline Total Bilirubin & $1.13 \pm 0.15$ & $2.82 \pm 1.28$ & $\mathbf{P}<0.01^{*}$ \\
\hline Direct Bilirubin & $7.96 \pm 2.57$ & $9.46 \pm 1.88$ & $\mathbf{P}<0.02$ \\
\hline Total protein & $52.35 \pm 2.67$ & $59.45 \pm 1.67$ & $\mathrm{P}<0.03^{*}$ \\
\hline Albumin & $23.56 \pm 2.67$ & $27.04 \pm 3.66$ & $P<0.04^{*}$ \\
\hline AST & $86.45 \pm 2.78$ & $89.45 \pm 3.98$ & $P=0.296^{\text {n.s }}$ \\
\hline ALT & $115.67 \pm 10.56$ & $101.56 \pm 8.78$ & $P=0.286^{n . s}$ \\
\hline ALK-Phosphatase & $130.56 \pm 10.34$ & $120.34 \pm .15 .34$ & $\mathrm{P}=0.263^{\mathrm{n} \cdot \mathrm{s}}$ \\
\hline
\end{tabular}

*: $P<0.05$ significant

Data described as $(n \& \%)$ chi-squar test and (mean $\pm S D)$ independent sample t-test

INR: international normalized ratio

ALT: Alanine transaminase

AST: Aspartate transaminase

ALK: Alkaline phosphatase

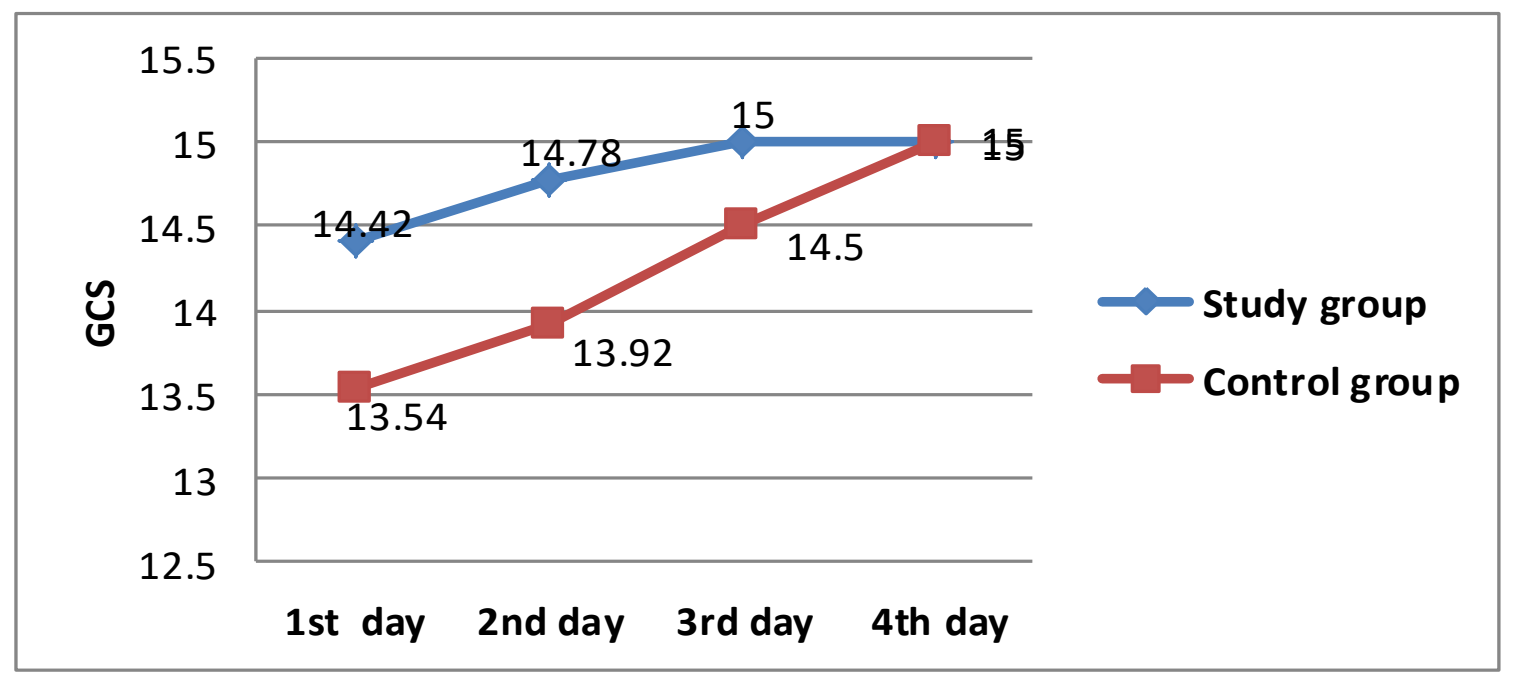

Fig (3): Comparison between both study and control groups in relation to Glasgow coma scale (GCS). 
Table (5): Mean comparison between both study and control groups in relation to Model for End-stage Liver Disease (MELD).

\begin{tabular}{|c|c|c|c|}
\hline $\begin{array}{c}\text { Model for End-stage Liver } \\
\text { Disease }\end{array}$ & Study group “n=50" & $\begin{array}{c}\text { Control group } \\
\text { "n=50" }\end{array}$ & \multirow{2}{*}{ Significance test } \\
\cline { 2 - 3 } & Mean $\mathbf{n}$ SD & Mean \pm SD & \\
\hline $\mathbf{1}^{\text {st }}$ day & $12.26 \pm 2.26$ & $13.20 \pm 6.70$ & $\mathbf{P}=\mathbf{0 . 3 7 3}$ '.s \\
\hline $\mathbf{2}^{\text {nd }}$ day & $13.89 \pm 7.85$ & $15.24 \pm 2.45$ & $\mathbf{P}<\mathbf{0 . 0 4}$ \\
\hline $\mathbf{3}^{\text {rd }}$ day & $13.89 \pm 3.54$ & $16.47 \pm 3.67$ & $\mathbf{P}<\mathbf{0 . 0 3}^{*}$ \\
\hline Discharge day from ICU & $14.67 \pm 2.65$ & $17.57 \pm 3.56$ & $\mathbf{P}<\mathbf{0 . 0 2}^{*}$ \\
\hline
\end{tabular}

*: $P<0.05$ significant

Data described as $(n \& \%)$ chi-squar test and (mean $\pm S D$ independent sample t-test

Table (6): Comparison between both study and control groups in relation to haematemesis mean scale.

\begin{tabular}{|c|c|c|c|}
\hline \multirow{2}{*}{ Gastrointestinal bleeding scale } & Study group “n=50" & $\begin{array}{c}\text { Control group } \\
\text { "n=50" }\end{array}$ & \multirow{2}{*}{ Significance test } \\
\cline { 2 - 3 } & Mean \pm SD & Mean \pm SD & \\
\hline 1st day & $1.00 \pm 0.00$ & $1.11 \pm 0.33$ & $\mathbf{P}=\mathbf{0 . 3 7 4}^{\text {n.s }}$ \\
\hline 2nd day & $1.02 \pm 0.23$ & $1.23 \pm 0.43$ & $\mathbf{P}=\mathbf{0 . 2 2 6}^{\text {n.s }}$ \\
\hline 3rd day & $1.11 \pm 0.46$ & $2.15 \pm 0.54$ & $\mathbf{P}<\mathbf{0 . 0 1}^{*}$ \\
\hline Discharge day from ICU & $1.00 \pm 0.00$ & $2.67 \pm 0.43$ & $\mathbf{P}<\mathbf{0 . 0 0}^{\text {1** }^{*}}$ \\
\hline
\end{tabular}

*: $P<0.05$ significant

Data described as $(n \& \%)$ chi-squar test and (mean $\pm S D$ independent sample t-test

Table (7): Percentage distribution between study and control group regard complication, and outcomes.

\begin{tabular}{|c|c|c|c|c|c|}
\hline \multirow{2}{*}{ Complications } & \multicolumn{2}{|c|}{ Study group " $n=50 "$} & \multicolumn{2}{|c|}{ Control group " $n=50 "$} & \multirow{2}{*}{ Significance test } \\
\hline & $\mathbf{N}$ & $\%$ & $\mathbf{N}$ & $\%$ & \\
\hline Hypovolemic shock & 1 & $2.0 \%$ & 4 & $8.0 \%$ & \multirow{5}{*}{$\mathbf{P}=\mathbf{0 . 0 3}^{*}$} \\
\hline Liver failure & 2 & $4.0 \%$ & 6 & $12.0 \%$ & \\
\hline Hepatorenal syndrome & 1 & $2.0 \%$ & 5 & $10.0 \%$ & \\
\hline Pulmonary edema & 1 & $2.0 \%$ & 3 & $6.0 \%$ & \\
\hline Infection & 1 & $2.0 \%$ & 6 & $12.0 \%$ & \\
\hline Mortality rate & 1 & $2.0 \%$ & 2 & $4.0 \%$ & \multirow{3}{*}{$P<0.004^{* *}$} \\
\hline \multicolumn{5}{|l|}{ ICU stay } & \\
\hline Mean \pm SD & \multicolumn{2}{|c|}{$3.08 \pm 0.27$} & \multicolumn{2}{|c|}{$4.34 \pm 0.55$} & \\
\hline
\end{tabular}

*: $P<0.05$ significant

Data described as $(n \& \%)$ chi-squar test and (mean \pm SD independent sample t-test

fig (1): Shows that the mean age in the study group $(46.54 \pm 4.72)$ years and $(43.76 \pm 2.98)$ years in the control group with no significant difference $\mathrm{p}$-value (0.383). also shows that more than half of patient in the study group were more than 30 years, male.

fig (2) shows that the percentage of male in the study group (52\%) and (68\%) in the control group. also shows that the percentage of female in the study group $(48 \%)$ of patient were $(32 \%)$ in the control group.

Table (1): Demonstrate that about quarter of both group had hypertension with no significant difference p-value (0.473). (32\%).
Table (2): Illustrate that total number of study group had pallor, abdominal tenderness (100\%), and majority of study complete had liver cirrhosis, in control group show majority of sample had pallor, abdominal tenderness $(98 \%, 90 \%$,) respectively with significant difference.

Table (3): Shows Comparison in relation to Hemodynamic state as regard temperature, it was found that the mean value of study group $(36.95 \pm 0.19)$ and $(37.08 \pm 0.13)$ in control group with no significance difference $(\mathrm{P}=0.375)$ in first day and show significance difference between both group in $4^{\text {th }}$ day $(\mathrm{P}<0.02)$. in relation to heart rate, respiratory rate, Systolic blood pressure, Diastolic blood 
pressure and oxygen saturation show no significance difference $(\mathrm{P}=0.638 \&$ 0.447), $(\mathrm{P}=0.362 \& 0.481)$, $(\mathrm{P}=0.473 \& 0.447),(\mathrm{P}=0.385 \& 0.386)$ and $(\mathrm{P}=0.274$ \& 0.300$)$ respectively. Regared MABP, it shows significance difference increase from $1^{\text {st }}$ to $4^{\text {th }}$ day in both group with no significance difference in fist day $(\mathrm{P}=0.385)$ and statistic significance difference in $4^{\text {th }}$ day $(\mathrm{P}<0.001)$.

Table (4): Shows laboratory data comparison in both group ,as regard blood test there were significance difference in both hemoglobin and hematocrit $(\mathrm{P}<0.03,0.04)$ respectively. Regard coagulation study also show significance difference between both group in Prothrombin time, Prothrombin concentration, INR withpvalue $(0.04,0.04,0.01)$ respectively. In comparison of electrolyte show no significance difference in $\mathrm{K}, \mathrm{Mg}$, Ca with p-value $(0.264,0.375$, $0.447)$ respectively, but there significance difference regard $\mathrm{Na}$ in both group $(\mathrm{P}<0.03)$. in relation to renal function test non significance difference regard urea $(\mathrm{P}=0.286)$ significance difference in create $(\mathrm{P}<0.02)$. also regard liver function test show significance difference in Total Bilirubin, Direct Bilirubin, Total protein, Albumin $(\mathrm{P}<0.01,<0.02,<0.03,<0.04)$ respectively.

fig (3): Shows significant increase in GCS score from $1^{\text {st }}$ to $4^{\text {th }}$ day in both groups with show significant difference in first day $(\mathrm{P}<0.02)$ between both group.

Table (5): Shows Model for End-stage Liver Disease (MELD) in study groups. There were non significance $(\mathrm{P}>0.05)$ between study \& control groups at day1, also there significance difference at day 4 $(\mathrm{P}<0.02)$.

Table (6): Shows Comparison of mean Gastrointestinal bleeding score between both study and conerol group, illustrate significant incease from $1^{\text {st }}$ to $4^{\text {th }}$ day $(\mathrm{P}=0.374 \& \mathrm{P}<0.001)$ respectively. Analyses score $(1.00 \pm 0.00 \& 1.11 \pm 0.33)$ in study and control group.

Table (7): Shows distribution of complication from the disease in study and control group and show significance difference $(\mathrm{P}=0.03)$. show that most common complication in study group was hepatic encephalopathy, liver failure with value $(16.0 \%$, $4.0 \%)$ respectively. value in control group was liver failure, infection and Hepatorenal syndrome with value $(12.0 \%, 12.0 \%$ and 10.0$)$ respectively, and shows significant difference between both group regard length of ICU stay p-value (0.004) with mean $(3.08 \pm 0.27$ and $4.34 \pm 0.55)$. There were higher in percentage in Mortality rate in control group thane study.

\section{Discussion}

Haematemesis is acommon medical emergency characterised by acute upper gastrointestinal bleeding.
Haemodynamic instability may also feature, with patients presenting with dizziness, syncope or in hypovolaemic shock. Despite the declining incidence of haematemesis, advances in therapeutic endoscopy and increased use of acid suppressing medication, there is a significant in-hospital mortality (Hea rnshaw, et al., 2011).

The role of the critical care nurse in managing a patient with haematemesis requires specific attention. In the first instance, the nurse will have a specific role in the nursing care that apatient in hypovolemic shock; also patient comfort can be maintained by assessing the need for analgesia. The nurse, who should be confident in (airway, breathing, circulation) resuscitation, will also be required to undertake ongoing assessment the patient's fluid and electrolyte status (Graeme, 2014)

The current study showed that there was no statistical significant difference between the study and control group in comparison to the demographic data in patients experience haematemesis, as regarding age distribution in the studied sample the more common age were over 30 years old in both group and in realtion to sex distribution it is common in male gender 26 and 34 in both group sequantly. This in line with study done by (Skok \& Sinkovic, 2011) documented that among total of 61 patients were treated in the MICU, Of these, 54 (6.3\%; 47 men, seven women; mean \pm SD age $61.6 \pm 14.2$ years) were treated for haematemesis. This in line with a study done by (Junaid Khan, 2018) The mean age of the patients was $43.3 \pm 13.80 .80(53.3 \%)$ of the patients were male and $70(46.7 \%)$ were females. This in line with a study done by (Casey, et al., 2015) Male patients outnumbered females by roughly 2:1 $(\mathrm{P}=0.01)$

In the current study, it was noticed that more than half of patient in the study group were more than 30 years, This opposite to study done by (Casey, et al., 2015) who note Of the total 2196,1920 patients The average age of the patient was approximately 52 years. The resarcher point of view that the incidence of viral hepatitis practically virus $\mathrm{C}$ is involved aung adult in assiut city because the people in this age more active and neglect following universal precautions.

Regarding study of past medical history in patient with haematemesis the result of current study revealed that quarter of both study group had history of hypertension and diabetes mellitus and nearly similar in both. Opposite to the study done by (Skok \& Sinkovic, 2011), the percent of hypertension and DM is common in his studied sample with rate of 24 and 18 percent sequantlty.

In the current study, it was noticed that most common finding in study and control groups had liver failure, 
Similar to results of the study done by $($ Peter \& Gregory, et al., 2011) who reported that more helpful is the clinical judgment that the patient who presents with haematemesis is suffering from liver failure. The resarcher point of view that the incidence of liver failure complication decrease when applying guidelines.

The spectrum of liver disease associated with Haematemesis is exceedingly broad. Both cirrhosis and noncirrhotic liver diseases may be complicated by episodes of haematemesis. The portal hypertension-induced bleeding varices of hepatosplenic schistosomiasis is one such example. Erosive gastritis with hemorrhage in the patient with fulminant viral or drug-induced hepatitis is another (Raymond \& Koff, 2014)

Careful haemodynamic monitoring in specialized intensive care units, with suitable supportive treatment, is one of the key measures involved in the treatment of patients with acute haemorrhage. In the current study, it was noticed that that no statistically significant differences regarding blood pressure. Opposite to study done by (Amany \& Shebl, et al 2013), who document that highly statistically significant differences regarding systolic blood pressure, in which the result recorded highly percentage $72.0 \%$ of the study group had increased in systolic blood pressure than $100 \mathrm{mmhg}$, while it recorded $24.0 \%$ in control groupe at $\mathrm{P}$ level $=(0.000)$. The resarcher point of view that the incidence of hypovolemic shock complication decrease with accurate monitoring and applying guidelines to patient at ICU.

In the current study, it was noticed that significance difference in both hemoglobin and hematocrit. Regard coagulation study also show significance difference between both group in Prothrombin time, Prothrombin concentration, INR. In relation to renal function test non significance difference regard urea significance difference in create . also regard liver function test show significance difference in total Bilirubin, direct bilirubin, total protein, albumin. This in line with study done by (Alberti, Santos, et al., 2016) who notably, laboratory abnormalities were similar across the ethnic groups, and included the findings of hemoglobin and hematocrit, elevated BUN, and slight elevations in INR and liver function teste consistent with haematemesis.

In the current study, it was noticed that significant increase in GCS score from $1^{\text {st }}$ to $4^{\text {th }}$ day in both groups. Opposite to study done by (Amany \& Shebl, et al., 2013 ) revealed that level of consciousness, the result showed that, the highest percentage $64.0 \%$ of the study group and $72.0 \%$ of the control group respectively was conscious.
In the current study, it was noticed that significant increase in GCS score from $1^{\text {st }}$ to $4^{\text {th }}$ day in both groups. Opposite to study done by (Amany \& Shebl, et al., 2013) revealed that level of consciousness, the result showed that, the highest percentage $64.0 \%$ of the study group and $72.0 \%$ of the control group respectively was conscious.

In the current study, it was noticed that there were non significance in relation to model for end-stage liver disease between study \& control groups at day1, also there significance difference at day 2, day 3 and day4. Opposite to study done by (Marmo, et al., 2008) observed a statistically significant increase, mean value: $18.07 \pm 7.74$ in the first episode versus $31.8 \pm 7.11$ to death, $\mathrm{P}<0.0001$.

In the current study, it was found that there was significant incease regarding haematemesis score between both study and control group from $1^{\text {st }}$ to $4^{\text {th }}$ day. Analyses study in control group this may be attributed that both groups received care which keep patients in stabilized condition and there are other multifactor affect haematemesis score rather than haematemesis.

The current study results illustrate that the length of ICU stay in study group less than control group with haematemesis sequanitaly with significant difference between both this indicate improvement of patient condition when applying guidelines for study group. This in the same line with (Skok \& Sinkovic, 2011) were mean length of stay in his study $2.8 \pm 1.9$. This in the same line with (Frank, 2014), who mention that length of intensive care unit stay for 240 studied patient was $12.5 \pm 5.2$ days. The resarcher point of view, application of national and international Guidelines decrease ICU stay for patient with haematemesis.

In the current study, it was noticed that develop infections such as bacteremia, spontaneous bacterial peritonitis, pneumonia, and urinary tract infections ( $2 \%$ in study group and $6 \%$ in control group).

Haematemesis is an extremely common clinical condition affecting a large patient population. The diverse clinical presentations, etiologic factors and treatment modalities are important to understand, and early identification of the source of bleeding is, the essential component in reducing morbidity and mortality. So, the present study was carried out to document information on the clinical outcome of patients admitted with haematemesis to a government hospital in Egypt with the intention of encouraging staff lead the provision of a protocol led service for these seriously ill patients who require urgent and skilled management. management of patients with haematemesis should include assessing the risk of gastrointestinal bleeding, minimizing the duration of exposure to anti platelet and antithrombotic agents in 
patients at high risk, and recognizing the early signs of bleeding (Mumtaz et al., 2008).

\section{Conclusion}

Based on the results of this study, it could be concluded that: implementing nursing guidelines on patients with haematemesis was significantly effective in outcomes of these patients.

\section{Recommendations}

Based on the study findings, the following recommendations are suggested

Emphasize the importance of accurate assessment of the patient with haematemesis.

Equip the gastroenterology intensive care unit at alrajhy liver hospital at assiut university with simple illustrated nursing guidelines for caring of haematemesis patient.

Repeat this research on a large sample size and different governmental hospital for generalization.

\section{References}

1. Aljebreen A., Fallone C., Barkun A., (2014): Nasogastric aspirate predicts high-risk endoscopic lesions in patients with acute upper-GI bleeding. Gastrointest Endosc;59:1728.

2. Amany M., Shebl, Salwa A., Mohamed, Walaa N., (2013): Effect of Nursing Intervention on Clinical Outcomes and Patient Satisfaction among Upper Gastrointestinal Bleeding, Journal of Natural Sciences Research, Vol.3, No.8, 2013

3. Alberti L., Santos R., Castro A., Fonseca Apdfp \& Key E., (2016) Upper Gastrointestinal Bleeding Patients. Gastroenterol Hepatol Open Access 4(6): 00123. DOI: 10.15406/ghoa.2016.04.00123

4. Cappell M., (2015): Initial management of acute upper gastrointestinal bleeding: from initial evaluation up to gastrointestinal endoscopy. Med Clin North Am; 92:491.

5. Casey, Bardou M., (2015): Therapeutic endoscopy for acute upper gastrointestinal bleeding. Nat Rev Gastroenterol Hepatol. 2015 Apr 7(4):21429.

6. Frank (2014): intravenous proton pump inhibitors: an evidence-based review of their use in gastrointestinal disorders. Drugs. 69:435.

7. Graeme D., Smith, Ph D., BA, RGN (2014): The management of acute upper gastrointestinal bleeding. Nursing Times; 100(26):40

8. Gado A., Ebeid B., Abdelmohsen A., Axon A., (2012): Clinical Outcome of Acute Upper
Gastrointestinal Hemorrhage among Patients Admitted to a Government Hospital in Egypt. The Saudi Journal of Gastroenterology; 18(1):34-39.

9. Green, S., Cheerio \& Laddie, (2011): Bidding Farewell to the Glasgow Coma Scale. Annals of emergency medicine, Vol 58 no (5) p.p: 427-430.

10. Hea rnshaw S., Logan R., \& Lowe D., (2011): Acute upper gastrointestinal bleeding in the UK: patient characteristics, diagnoses and outcomes in the 2011 UK audit. 60:132735.

11.Jairath V., Hearnshaw S., Brunskill S., (2010): Red cell transfusion for the management of upper gastrointestinal haemorrhage . Cochrane Database Syst Rev, CD006613.

12. Junaid Khan (2018): Management of upper gastrointestinal bleeding MedcClin North Am ; 80:1035.

13. Kwan V., Norton I., (2017): Endoscopic management of upper gastrointestinal haemorrhage. ANZ J Surg 77(4): 222-230.

14. McIntyre L., Hebert P., \& Fergusson D., (2015): A survey of Canadian intensivists' resuscitation practices in early septic shock. Critical Care 11(4): 74.

15. Mumtaz K., Ismail F., \& Jafri W., (2008): Safety and utility of oesophago-gastroduodenoscopy in acute myocardial infarction. Gastroenterol Hepatol. ,20:51-55.

16. Marmo R., Koch M., Cipolletta L., Capurso L., \&Pera A., (2008): Predictive factors of mortality from nonvariceal upper gastrointestinal hemorrhage: a multicenter study. Am J Gastroenterol 103: 1639-1647

17. Ortiz M., Córdoba J., \& Doval E., (2017): Development of a clinical hepatic encephalopathy staging scale. Aliment Pharmacol Ther; 26:859-867.

18. Peter D., \& Gregory J., (2011): Evaluation of the patient with gastrointestinal bleeding: an evidence based approach. Emerg Med Clin North Am 17(1): 239-261.

19. Reintam A., (2014): Emergency Department Evaluation and Management of Patients with Upper Gastrointestinal Bleeding; 17(4): 1-20.

20. Rudolph S., Landsverk B., Freeman M., (2013): Endotracheal intubation for airway protection during endoscopy for severe upper GI hemorrhage. Gastrointest Endosc 57(1): 5861.

21. Raymond \& Koff (2014): Emergency Department Evaluation and Management of 
Patients with Upper Gastrointestinal Bleeding; 17(4): $1-20$

22. Skok P., \& Sinkovic A., (2011): Upper Gastrointestinal Haemorrhage:Predictive Factors of In-hospital Mortality in Patients Treated in the Medical Intensive Care Unit, The Journal of International Medical Research, 2011; 39: $1016-1027$

23. Smith, G., (2014): The management of acute upper gastrointestinal bleeding. $\mathrm{Nu} 35$.

24. Said A., Williams J., \& Holden J., (2014) Model for end stage liver disease score predicts mortality across a broad spectrum of liver disease. 2014; 100(26), 40:897.

25. World Health Organization. (2016): Gastrointestinal bleeding scale; 22(6):864873.

26. (http://strokengine, 2006). 